NOTE

\title{
DNA identification of ciliates associated with disease outbreaks in a New Zealand marine fish hatchery
}

\author{
P. J. Smith ${ }^{1, *}$, S. M. McVeagh1 ${ }^{1}$ D. Hulston' ${ }^{1}$, S. A. Anderson ${ }^{1}$, Y. Gublin² \\ ${ }^{1}$ National Institute of Water and Atmospheric Research (NIWA), Private Bag 14901, Wellington, New Zealand \\ ${ }^{2}$ NIWA, Station Road, Ruakaka, Northland 0166, New Zealand
}

\begin{abstract}
Ciliates associated with fish mortalities in a New Zealand hatchery were identified by DNA sequencing of the small subunit ribosomal RNA gene (SSU rRNA). Tissue samples were taken from lesions and gill tissues on freshly dead juvenile groper, brain tissue from adult kingfish, and from ciliate cultures and rotifers derived from fish mortality events between January 2007 and March 2009. Different mortality events were characterized by either of 2 ciliate species, Uronema marinum and Miamiensis avidus. A third ciliate, Mesanophrys carcini, was identified in rotifers used as food for fish larvae. Sequencing part of the SSU rRNA provided a rapid tool for the identification and monitoring of scuticociliates in the hatchery and allowed the first identification of these species in farmed fish in New Zealand.
\end{abstract}

KEY WORDS: Small subunit ribosomal RNA gene - Scuticociliatosis - Uronema marinum . Miamiensis avidus $\cdot$ Mesanophrys carcini $\cdot$ Groper $\cdot$ Polyprion oxygeneios $\cdot$ Kingfish $\cdot$ Seriola lalandi

\section{INTRODUCTION}

The scuticociliates are major pathogens in marine fin-fish aquaculture and have caused mass mortalities in a range of farmed fishes (Kim et al. 2004a, Jung et al. 2005, 2007, Paramá et al. 2006) and crustacea (see Jung et al. 2005). Ciliates infect the gills, skin, muscles and internal organs and can be highly histophagous, destroying infected tissues. Several species of opportunistic scuticociliates have been implicated in systemic infections of farmed fish (Paramá et al. 2006), although identification of the parasite species involved in scuticociliatosis can be difficult with traditional microscopy methods (Song \& Wilbert 2000, Paramá et al. 2006). DNA methods are increasingly used for specimen identification of a wide range of taxa (e.g. Hebert et al. 2003). The small subunit ribosomal RNA (SSU rRNA, 18S) region has been used for the identification of ciliate pathogens in fin-fish farms (Kim et al. 2004a,b, Jung et al. 2007) and in crustacea (Ragan et al. 1996), and for phylogenetic and taxonomic studies of ciliates (Hirt et al. 1995, Affa'a et al. 2004). Jung et al. (2005) have described the complete SSU rRNA sequence of the pathogenic scuticociliate Miamiensis avidus; subsequently synonymy between Philasterides dicentrarchi and M. avidus was suggested based on SSU rRNA sequences (Paramá et al. 2006). There is a growing DNA database of ciliate SSU rRNA sequences available on GenBank which can be utilised to match sequences and identify unknown ciliates.

Most DNA studies have used cultured ciliates or cloned DNA product to avoid amplification of host tissues (Kim et al. 2004a, Song et al. 2009). Here we evaluate the application of DNA sequencing for the identification of ciliates in direct amplification of fish tissues. We report the DNA identification of ciliates associated 
with fish mortalities in a marine fish hatchery in northern New Zealand, in particular hatchery-reared juveniles of groper Polyprion oxygeneios (Schneider et Forster, 1801) and adult kingfish Seriola lalandi Valenciennes, 1833, and demonstrate that different mortality events were characterized by 2 ciliate species over a 2 yr time period. This is the first record of these ciliate species associated with mortalities in farmed fish in New Zealand.

\section{MATERIALS AND METHODS}

Small subsamples of tissue ( 200 mg) were taken from skin lesions and gill tissues of juvenile groper (22 to $60 \mathrm{~mm}$ fork length) that had been frozen at $-20^{\circ} \mathrm{C}$ or fixed in 5 volumes of $90 \%$ ethanol soon after mortalities occurred in the hatchery. Adult kingfish which had died in the hatchery were dissected and small subsamples of tissues fixed in 5 volumes of $90 \%$ ethanol. Live ciliates isolated from dead groper and from water samples taken from groper juvenile tanks exhibiting a high fish mortality, were cultured in L-15 (Leibovitz) medium with L-glutamine and filtered seawater following methods described by Iglesias et al. (2002). Ciliates reached densities of $10^{4} \mathrm{l}^{-1}$ seawater in the groper juvenile tanks. Cultures were centrifuged to a pellet and resuspended in $90 \%$ ethanol for DNA analysis. Rotifers used as live food for larval groper, also exhibited mortalities associated with ciliates and were fixed in $90 \%$ ethanol. Muscle tissue samples were taken from wild-caught specimens of groper and kingfish, and DNA extracted following methods used for ciliates.

Total genomic DNA was extracted from fish tissues, rotifers, and ciliate pellets by homogenisation and overnight digestion with Proteinase $\mathrm{K}$ at $55^{\circ} \mathrm{C}$, followed by a phenol-chloroform-ethanol procedure (Taggart et al. 1992). The universal primer pair designed to amplify the SSU rRNA gene of ciliates (Sogin 1990) was trialled and the internal primers developed by Jung et al. (2005) used to amplify smaller subregions of the SSU rRNA gene (Table 1). DNA amplification procedures followed those used at

Table 1. Primers used to amplify the small subunit (SSU) rRNA gene in ciliates and host fishes in New Zealand

\begin{tabular}{|lll|}
\hline Code & Sequence & Source \\
\hline Cil A & 5'-ACC TGG TTG ATC CTG CCA GT & Sogin (1990) \\
Cil B & 5'-TGA TCC TTC TGC AGG TTC ACC TAC & Sogin (1990) \\
Cil 2 & 5'-CTA TCA GCT TTC GAT GGT & Jung et al. (2005) \\
Cil 3 & 5'-GTA GGC TCT TTA CCT TGA & Jung et al. (2005) \\
Cil 4 & 5'-CAA ATC ACT CCA CCA ACT & Jung et al. (2005) \\
Cil 5 & 5'-ACG ACT TCT CCT TCC TCT & Jung et al. (2005) \\
\hline
\end{tabular}

NIWA, using a Cetus 9600 DNA thermocycler (PerkinElmer). Amplifications were carried out using an initial denaturation of $94^{\circ} \mathrm{C}$ for $2 \mathrm{~min}$, followed by 40 cycles of $94^{\circ} \mathrm{C}$ for $60 \mathrm{~s}, 50^{\circ} \mathrm{C}$ for $60 \mathrm{~s}$, and $72^{\circ} \mathrm{C}$ for $120 \mathrm{~s}$, and a final extension at $72^{\circ} \mathrm{C}$ for $7 \mathrm{~min}$. The sizes of the amplified products were checked by electrophoresis in $1.5 \%$ agarose gels, stained with ethidium bromide. Those amplifications that produced a single amplified product were selected for sequencing (see Table 2). DNA products were labeled using the BigDye® Terminator v3.1 Cycle Sequencing Kit (Applied Biosystems) and sequenced using an ABI 3730 capillary sequencer following manufacturer's instructions. Sequencing was conducted in both directions, and the 2 sequences joined and aligned. The sequences were edited in CHROMAS (Technelysium, Queensland), aligned in CLUSTAL in MEGA version 3 (Kumar et al. 2004) and stored in BIOEDIT (Hall 1999). The sequences were submitted to GenBank in a BLAST search to identify the closest matching species; only matches greater than $98 \%$ identity were considered. Sequences derived from tissue samples from dead fish, dead rotifers, the cultured ciliates, and fish hosts were aligned against GenBank SSU rRNA entries for ciliates and marine fishes. Currently there are no SSU rRNA sequences available for groper and kingfish.

A neighbour-joining (NJ) tree was created using the software MEGA3 (Kumar et al. 2004) to provide a graphic representation of the divergence among the unknown ciliates from New Zealand and the 98\%+ matched sequences derived from GenBank. Modeltest version 3.7 (Posada \& Crandall 1998) was used to determine the best-fit model using likelihood ratio tests, and the Tamura-Nei (TrN) distance model selected (Tamura \& Nei 1993); bootstrapping was performed with 1000 replications.

\section{RESULTS AND DISCUSSION}

Several primer pairs trialled on the tissue samples, cultured ciliates, and rotifers produced a single amplified fragment. However, following sequencing, not all of these fragments were from ciliates. The universal primer pair Cil 2/Cil 5 and the CilA/Cil 4 pair (Table 1) amplified single fragments with most tissue samples, but preferentially amplified fish host tissue, groper or kingfish; only samples of cultured ciliates and rotifers produced ciliate-specific fragments. The primer pairs Cil 3/Cil 4 and Cil 2/Cil 4 always amplified a ciliate fragment, even in tissue samples taken from fish lesions and 
Table 2. Small subunit (SSU) rRNA results for fish tissues, ciliate cultures, and rotifers tested from fish mortality events between February 2007 and March 2009. All juvenile groper were derived from one hatchery in Bream Bay, but the 2008-09 juveniles were on-grown in 2 locations: BB: Bream Bay hatchery; GP: Greta Point aquarium facility. Numbers in parentheses: number of specimens or cultures

\begin{tabular}{|lcccccc|}
\hline Specimen & $\begin{array}{c}\text { Tissue } \\
\text { source }\end{array}$ & $\begin{array}{c}\text { Sample } \\
\text { date }\end{array}$ & $\begin{array}{c}\text { Sequence } \\
\text { length (bp) }\end{array}$ & $\begin{array}{c}\text { Primer } \\
\text { pair }\end{array}$ & $\begin{array}{c}\text { Identity } \\
(\%)\end{array}$ & Identification \\
\hline Kingfish & Brain & Feb 07 & 500 & Cil 3/Cil 4 & 98 & Miamiensis avidus \\
Kingfish & Brain & Nov 08 & 518 & Cil 3/Cil 4 & 99 & Miamiensis avidus \\
Juvenile groper (2) & Skin lesions & Jan 07 & $505-527$ & Cil 3/Cil 4 & $98-99$ & Miamiensis avidus \\
Juvenile groper (2) & Skin lesions & Dec 07 & 505 & Cil 3/Cil 4 & 99 & Uronema marinum \\
Ciliate & Cultures (4) & Dec 07 & 1300 & Cil 2/Cil 5 & $99-100$ & Uronema marinum \\
Juvenile groper & Skin lesion & Jan 08 & 500 & Cil 3/Cil 4 & 99 & Uronema marinum \\
Juvenile groper (4) & Skin lesions & Mar 08 & $510-525$ & Cil 3/Cil 4 & $99-100$ & Miamiensis avidus \\
Ciliate & Cultures (6) & Mar 08 & 1360 & Cil 2/Cil 5 & $99-100$ & Miamiensis avidus \\
Rotifer & Larval tank & Sep 08 & 1080 & Cil 2/Cil 5 & 99 & Mesanophrys carcini \\
Rotifer & Larval tank & Sep 08 & 1200 & Cil 2/Cil 5 & 99 & Mesanophrys carcini \\
Juvenile groper BB (3) & Gills & Jan 09 & 523 & Cil 3/Cil 4 & 99 & Miamiensis avidus \\
Juvenile groper BB (5) & Skin lesions & Jan 09 & $490-510$ & Cil 3/Cil 4 & 99 & Miamiensis avidus \\
Juvenile groper BB (3) & Skin lesions & Feb 09 & $511-520$ & Cil 3/Cil 4 & 99 & Miamiensis avidus \\
Juvenile groper GP (4) & Gills & Jan 09 & $508-512$ & Cil 3/Cil 4 & 99 & Miamiensis avidus \\
Juvenile groper GP (4) & Gills & Feb 09 & $497-505$ & Cil 3/Cil 4 & 100 & Miamiensis avidus \\
Juvenile groper GP (8) & Gills \& skin lesions & Mar 09 & $505-529$ & Cil 3/Cil 4 & 99 & Miamiensis avidus \\
\hline
\end{tabular}

gills. Sequences for the New Zealand ciliates have been deposited in GenBank, Accession Nos.: Miamiensis FJ936000, Uronema FJ936001, and Mesanophrys FJ936002.

The suspect ciliates could be identified to the species level with 99 to $100 \%$ identity matches against sequences held in GenBank; results are summarized in Table 2 and Fig. 1. Sequences from the host fish, groper and kingfish, matched against marine fishes, with 97 and $96 \%$ identities to Epinephelus moara (GenBank Accession No. FJ176794.1) and Auxis rochei (GenBank Accession No. AB193747.1), respectively, reflecting the limited number of fish species sequenced for this DNA region.

Three species of scutiociliate were identified from the New Zealand SSU rRNA gene sequences (Table 2 and Fig. 1), but only 2 species were associated with fish mortalities. Uronema marinum was the only ciliate identified in dead juvenile groper in the hatchery during the southern summer 2007-08, while Miamiensis avidus was associated with juvenile groper mortalities in summer 2006-07 and summer 2008-09, and adult kingfish mortalities in February 2007 and November 2008. Even though the ciliates were identified in dead fish, they might not have been the primary cause of mortalities but a secondary invasion in stressed or damaged fish. Fin damage is common in hatchery reared juvenile groper, especially the spiny dorsal and pectoral fins, and opportunistic ciliates may invade damaged tissues. Other ciliates are known to enter fish hosts via existing lesions (Paramá et al. 2003), and both
$U$. marinum and $M$. avidus are known pathogens in marine fish farms and coastal waters in the northern hemisphere (e.g. Jung et al. 2005, 2007). The first signs of scuticociliatosis in juvenile groper were skin lesions, typically haemorrhagic lesions at the base of the fins, with moribund fish exhibiting loss of balance (L. Tubbs, NIWA, pers. comm.). Once external lesions were noted the progression of the disease was rapid with death occurring within 24 to 48 h (Y. Gublin pers. obs.).

Uronema marinum and Miamiensis avidus have not been previously identified in New Zealand waters and might be cosmopolitan species, alternatively the New Zealand specimens might be closely related species that have not diverged from their northern sister taxa in the SSU rRNA gene. Some species such as U. nigricans appear to be cosmopolitan and adapted to live in marine and freshwater environments (Crosbie \& Munday 1999) as are other ciliates (Finlay et al. 1999). Faster-evolving regions of DNA will be required to assess the phylo-geographic relationships among the northern and southern scutiociliates. In this respect, DNA fingerprinting of the morpho-species Parauronema virginianum has indicated a possible species complex (Shang \& Song 2005).

A third scutiociliate, Mesanophrys carcini, was associated with rotifer but not groper mortalities in the hatchery. $M$. carcini is known to cause scuticociliatosis in farmed turbot Scophthalmus maximus in China (Wang et al. 2005), where it is a common ciliate in coastal waters and in marine farms (Shang et al. 2003), 


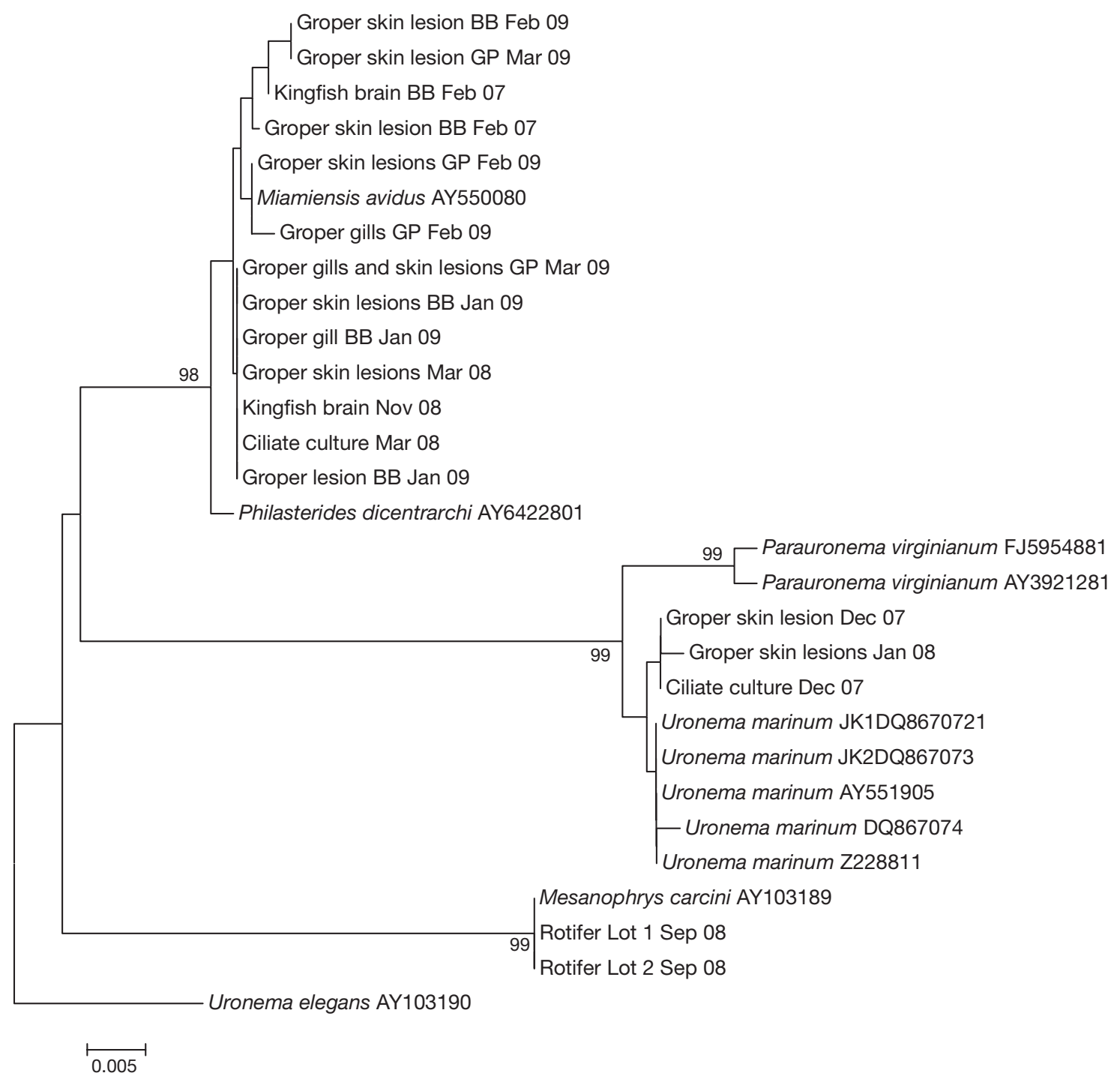

Fig. 1. Small subunit (SSU) rRNA neighbour-joining tree based on Tamura-Nei (TrN) distances used for identification of unknown ciliates in fish hatcheries in New Zealand. The tree has been rooted with Uronema elegans. Numbers at nodes are bootstrap percentages (>75\%) after 1000 replicates. BB: Bream Bay hatchery; GP: Greta Point aquarium. GenBank Accession Nos. are given after species names

and is a known pathogen in the northern hemisphere crab Cancer pagurus (Bower 1996), and will need to be monitored in future fish mortalities in the New Zealand hatchery.

Use of the ciliate specific primers allows direct amplification from fish tissues taken from dead and dying fish with out the need for cloning or culturing, and although shorter DNA sequences are obtained with the ciliate specific primers (400 to $500 \mathrm{bp}$ ), there was sufficient divergence in this DNA subregion to identify ciliates to the species level. Paramá et al. (2006) were similarly able to identify Miamiensis avidus in juvenile turbot with a $350 \mathrm{bp}$ product of the $18 \mathrm{~S}$ rDNA. An RFLP test, based on presence and absence of restriction enzyme sites, identified with the programme Webcutter 2.0 (http://users.unimi.it/ camelot/tools/cut2.html) has been designed to distinguish the 3 ciliate species identified in the 2007-09 mortalities and will provide a more rapid molecular identification tool for ciliates in New Zealand fish hatcheries, but may not discriminate additional species. DNA sequencing will be required to confirm ciliate identities at the start of fish mortality events. The $\sim 500 \mathrm{bp}$ sequence of the SSU rRNA gene, amplified with the Cil 3/Cil 4 primer pair that selectively amplify ciliate DNA in fish tissues, provides diagnostic bases that distinguish recognised taxa, and will be used as a monitoring tool to identify ciliates in the hatchery. 
Acknowledgements. We thank Prof. S. J. Jung (Yosu National University, South Korea) for information on ciliate primers and L. Tubbs (NIWA), who first alerted us to the ciliate problem in the Bream Bay hatchery. The project was supported with funding from the New Zealand Foundation for Research, Science and Technology, contract C01X0710.

\section{LITERATURE CITED}

Affa'a FM, Hickey DA, Struder-Kypke MA, Lynn DH (2004) Phylogenetic position of species in the genera Anoplophrya, Plagiotoma, and Nyctotheroides (Phylum Ciliphora), endosymbiotic ciliates of annelids and anurans. J Eukaryot Microbiol 51:301-306

Bower S (1996) Synopsis of infectious diseases and parasites of commercially exploited shellfish: Mesanophrys spp. (ciliate disease) of crabs. www.pac.dfo-mpo.gc.ca/ science/species-espaces/shellfish-coquillages/diseasesmaladies/pages/mesancb_e.htm

Crosbie PPB, Munday BL (1999) Environmental factors and chemical agents affecting the growth of the pathogenic marine ciliate Uronema nigricans. Dis Aquat Org 36: 213-219

Finlay B, Esteban G, Olmo J, Tyler P (1999) Global distribution of free-living microbial species. Ecography 22: $138-144$

Hall T (1999) Bioedit: a user friendly biological sequence alignment editor and analysis programme for Windows 95/98/NT. Nucleic Acids Symp Ser 41:95-98

Hebert P, Cywinska A, Ball S, deWaard J (2003) Biological identifications through DNA barcodes. Proc R Soc Lond B Biol Sci 270:313-322

Hirt RP, Dyal PL, Wilkinson M, Finlay BJ, Roberts DM, Embley TM (1995) Phylogenetic relationships among karyorelictids and heterotrichs inferred from small subunit rRNA sequences: resolution at the base of the ciliate tree. Mol Phylogenet Evol 4:77-87

Iglesias R, Paramá A, Álvarez MF, Leiro J, Sanmartín M (2002) Antiprotozoals effective in vitro against scuticociliate fish pathogen Philasterides dicentrarchi. Dis Aquat Org 49:191-197

Jung SJ, Kitamura SI, Song JY, Joung IY, Oh MJ (2005) Complete small subunit rRNA gene sequence of the scuticociliate Miamiensis avidus pathogenic to olive flounder Paralichthys olivaceus. Dis Aquat Org 64:159-162

Jung SJ, Kitamura SI, Song JY, Oh MJ (2007) Miamiensis avidus (Ciliophora: Scuticociliatida) causes systematic infection of olive flounder Paralichthys olivaceus and is a senior synonym of Philasterides dicentrarchi. Dis Aquat Org 73:227-234

Kim SM, Cho JB, Kim SK, Nam YK, Kim KH (2004a) Occurrence of scuticociliatosis in olive flounder Paralichthys olivaceaus by Phiasterides dicentrarchi (Ciliophora: Scuticociliatida). Dis Aquat Org 62:233-238

Editorial responsibility: Dieter Steinhagen,

Hannover, Germany
Kim SM, Cho JB, Lee EH, Kwon SR, Kim SK, Nam YK, Kim KH (2004b) Pseudocohnilembus persalinus (Ciliophora: Scuticociitida) is an additional species causing scuticociliatosis in olive flounder Paralichthys olivaceus. Dis Aquat Org 62:239-244

> Kumar S, Tamura K, Nei M (2004) MEGA3: integrated software for molecular evolutionary genetics analysis and sequence alignment. Brief Bioinform 5:150-163

Paramá A, Iglesias R, Álvarez MF, Leiro J, Aja C, Sanmartín ML (2003) Philasterides dicentrarchi (Ciliophora, Scuticociliatida): experimental infection and possible routes of entry in farmed turbot (Scophthalmus maximus). Aquaculture 217:73-80

- Paramá A, Arranz JA, Álvarez MF, Sanmartín ML, Leiro J (2006) Ultrastructure and phylogeny of Philasterides dicentrarchi (Ciliophora, Scuticociliatia) from farmed turbot in NW Spain. Parasitology 132:555-564

Posada D, Crandall K (1998) MODELTEST: testing the model of DNA substitution. Bioinformatics 14:817-818

> Ragan MA, Cawthorn RJ, Despres B, Murphy CA, Singh RK, Loughlin MB, Bayer RC (1996) The lobster parasite Anophryoides haemophila (Scuticociliatida: Orchitophryidae): nuclear 18S rDNA sequence, phylogeny and detection using oligonucleotide primers. J Eukaryot Microbiol 43:341-346

Shang H, Song W (2005) Separation and relationship of 10 marine scuticociliates (Protozoa, Ciliophora) using RAPD fingerprinting method. Acta Oceanol Sin 24:78-85

Shang H, Song W, Warren A (2003) Phylogenetic positions of 2 ciliates, Paranophrys magna and Mesanophrys carcini (Protozoa, Ciliophora, Oligohymenophorea), within the subclass Scuticociliatia inferred from complete small subunit rRNA gene sequences. Acta Protozool 42:171-181

Sogin ML (1990) Amplification of ribosomal RNA genes for molecular evolution studies. In: Innis MA, Gelfand DH, Sninsky JJ, White TJ (eds) PCR protocols: a guide to methods and applications. Academic Press, San Diego, CA

Song W, Wilbert N (2000) Redefinition and redescription of some marine scuticociliates from China, with report of a new species, Metanophrys sinensis nov. spec. (Ciliophora, Scuticociliatida). Zool Anz 239:45-74

Song JY, Kitamura SI, Oh MJ, Kang HS, Lee JH, Tanaka SJ, Jung SJ (2009) Pathogenicity of Miamiensis avidus (syn. Philasterides dicentrarchi), Pseudocohnilembus persalinus, Pseudocohnilembus hargisi and Uronema marinum (Ciliophora, Scuticociliatida). Dis Aquat Org 83:133-143

Taggart JB, Hynes RA, Prodohl PA, Ferguson A (1992) A simplified protocol for routine total DNA isolation from salmonid fishes. J Fish Biol 40:963-965

Tamura K, Nei M (1993) Estimating the number of nucleotide substitutions in the control region of mitochondrial DNA in humans and chimpanzees. Mol Biol Evol 10:512-526

Wang Yg, Chen Jj, Qin L (2005) Mesanphrys carcini causing severe scuticociliatosis in farmed turbot Scophthalmus maximus in China. J Fish Sci China 12:594-601

Submitted: April 20, 2009; Accepted: June 30, 2009

Proofs received from author(s): September 4, 2009 